\title{
Long-term loblolly pine land use reduces methane and net greenhouse gas emissions in a subtropical Cambisol, despite increasing nitrous oxide
}

\author{
Murilo G. Veloso ${ }^{1} \cdot$ Jeferson Dieckow $^{1}$ (D) Josiléia Acordi Zanatta ${ }^{2} \cdot$ Maico Pergher $^{1} \cdot$ Cimélio Bayer $^{3}$. \\ Rosana C. V. Higa ${ }^{2}$
}

Received: 7 January 2019 / Accepted: 29 July 2019 / Published online: 14 August 2019

(C) INRA and Springer-Verlag France SAS, part of Springer Nature 2019

\begin{abstract}
- Key message In loblolly pine land use of 17-32 years following forest clearing, $\mathrm{CH}_{4}$ consumption and $\mathrm{N}_{2} \mathrm{O}$ emission diminished by 17 years, due to high soil moisture ( $\sim 80 \%$ WFPS, $\mathrm{N}_{2} \mathrm{O}$ into $\mathrm{N}_{2}$ ), but increased by 32 years, where medium moisture favoured methanotrophy and denitrification into $\mathrm{N}_{2} \mathrm{O}$. Soil greenhouse gases (GHG) emission was positive by 17 years, but negative by 32 , when soil sequestered carbon.

- Context Much of the role of planted forests in the gaseous soil-atmosphere exchanges in the subtropics remains to be evaluated. - Aims To assess the impacts of loblolly pine (Pinus taeda L.) on soil nitrous oxide $\left(\mathrm{N}_{2} \mathrm{O}\right)$ and methane $\left(\mathrm{CH}_{4}\right)$ fluxes in a subtropical Cambisol.

- Methods Fluxes were monitored over 1 year with static chambers, in forest stands under natural forest (NF) and pine plantation for 17 (P17) and 32 years (P32).

- Results The NF soil showed the lowest $\mathrm{N}_{2} \mathrm{O}$ emission and the highest $\mathrm{CH}_{4}$ consumption, because of the lowest water-filled pore space (WFPS, $<40 \%$ ) and highest soil macroporosity. In P17, $\mathrm{N}_{2} \mathrm{O}$ emission was still low, but $\mathrm{CH}_{4}$ consumption diminished sixfold, possibly because of the predominance of methanotrophy, favoured by the highest WFPS ( 80\%) and lowest macroporosity that together with low mineral $\mathrm{N}$ concentration also did not favour the formation of $\mathrm{N}_{2} \mathrm{O}$. In $\mathrm{P} 32$, the improved soil mineral $\mathrm{N}$, macroporosity and intermediate WFPS $(\sim 60 \%)$ increased $\mathrm{CH}_{4}$ consumption and also $\mathrm{N}_{2} \mathrm{O}$ emission, in an environment supposedly favourable to methanotrophy and also to $\mathrm{N}_{2} \mathrm{O}$ production. Considering soil organic carbon (SOC) from a concurrent study, the net GHG emission $\left(\mathrm{Mg} \mathrm{C}_{\mathrm{eq}}\right.$ ha $^{-1}$ year $\left.^{-1}\right)$ was 2.8 in P17 and -1.1 in P32.
\end{abstract}

\section{Handling Editor: Erwin Dreyer}

Contribution of the co-authors Murilo G. Veloso contributed with field sampling, laboratory analyses, data interpretation and writing the manuscript.

Jeferson Dieckow contributed with laboratory analyses, data interpretation and revision and translation of this manuscript.

Josiléia Acordi Zanatta contributed with field sampling, laboratory analyses, data interpretation and the revision of this manuscript.

Maico Pergher contributed with the field sampling, laboratory analyses and data interpretation.

Cimélio Bayer contributed with greenhouse gases analysis and the revision of this manuscript.

Rosana C. V. Higa contributed with the experiment planning and initial ideas for this study.

Jeferson Dieckow

jefersondieckow@ufpr.br

1 Departamento de Solos e Engenharia Agrícola e Programa de Pós-Graduação em Ciência do Solo, Universidade Federal do Paraná, Rua dos Funcionários 1540, Curitiba, PR 80035-050, Brazil
2 Embrapa Florestas, Estrada da Ribeira km 111, Colombo, PR 83411-000, Brazil

3 Departamento de Solos, Universidade Federal do Rio Grande do Sul, Av. Bento Gonçalves 7712, Porto Alegre, RS 91540-000, Brazil 
- Conclusion Soil under pine plantation is the source of GHG in the first rotation (17 years), because of the low $\mathrm{CH}_{4}$ consumption and SOC losses, but soil becomes $\mathrm{C}$ sink in the second rotation (32 years), by sequestering SOC and consuming more $\mathrm{CH}_{4}$, despite emitting more $\mathrm{N}_{2} \mathrm{O}$.

Keywords Reforestation $\cdot$ GHG intensity $\cdot$ Ammonium $\cdot$ Nitrate $\cdot$ Temperature $\cdot$ Southern Brazil

\section{Introduction}

Afforestation, reforestation and deforestation avoidance are some of the strategies to mitigate anthropogenic emissions of greenhouse gases (GHG) because they can potentially sequester 2.3$5.7 \mathrm{Gt} \mathrm{CO}_{2 \text { eq }}$ year $^{-1}$ (deforestation avoidance not included) (Smith et al. 2013) and so partly offset the global emission of $49 \mathrm{Gt} \mathrm{CO}_{2 \mathrm{eq}}$ year $^{-1}$ (IPCC 2014). In the Paris Climate Agreement, forests are expected to have an outstanding contribution by reducing in a quarter the emission from the countries that planned their Nationally Determined Contributions (Grassi et al. 2017).

Yet, much of the role of planted forests at mitigating the soil-atmosphere exchanges of nitrous oxide $\left(\mathrm{N}_{2} \mathrm{O}\right)$, methane $\left(\mathrm{CH}_{4}\right)$ and carbon dioxide $\left(\mathrm{CO}_{2}\right)$ still remains to be evaluated, particularly in forest plantations of the tropics and subtropics. Besides the standing vegetation, soil is a key carbon reservoir in forest ecosystems ( $\mathrm{Lal} 2004)$, being capable of sequestering up to $3.1 \mathrm{Mg} \mathrm{C}^{-1}$ year $^{-1}$ in tropical and subtropical regions (Post and Kwon 2000). However, a full account of soil managements on GHG mitigation must also include the $\mathrm{N}_{2} \mathrm{O}$ and $\mathrm{CH}_{4}$ soil-atmosphere exchanges (Christiansen and Gundersen 2011; Gregorich et al. 2005). That full account can be expressed in terms of net GHG emission, which adds up soil organic carbon (SOC) changes and soil $\mathrm{N}_{2} \mathrm{O}$ and $\mathrm{CH}_{4}$ emissions (Mosier et al. 2005). Another parameter useful to measure the impact of forest ecosystems on GHG emission is the GHG intensity (GHGi) (Mosier et al. 2006), the emission per unit of product produced (e.g. wood).

The age of the forest land use might be a factor that controls soil $\mathrm{N}_{2} \mathrm{O}$ and $\mathrm{CH}_{4}$ emissions (Ball et al. 2007; Christiansen and Gundersen 2011; Peichl et al. 2010), because production and consumption of those gases are intimately related to soil attributes that may change on the development course of the forest land use, like soil porosity and water-filled pore space (WFPS). The two most important processes of $\mathrm{N}_{2} \mathrm{O}$ production are nitrification and denitrification (Firestone and Davidson 1989; Robertson and Groffman 2007; Wrage et al. 2001), which depend mainly on soil nitrogen availability and redox potential (Davidson et al. 2000). For $\mathrm{CH}_{4}$, fluxes are governed basically by the balance between methanogenesis and methanotrophy (Le Mer and Roger 2001), and increase in $\mathrm{CH}_{4}$ consumption by soil over increasing forest land use time has been reported (Peichl et al. 2010). Therefore, with soil structure amelioration during long-term forest land use
(Fisher 1995), more aerated/oxidative soil conditions that would disfavour $\mathrm{N}_{2} \mathrm{O}$ production by denitrification and increase $\mathrm{CH}_{4}$ consumption by methanotrophy are expected.

We hypothesised that long-term loblolly pine land use in the subtropics decreases $\mathrm{N}_{2} \mathrm{O}$ emission and increases $\mathrm{CH}_{4}$ consumption because of improvements in soil structure and aeration, thus contributing to mitigation of soil GHG emissions. This study aimed at assessing the contributions of subtropical loblolly pine plantations to mitigate soil net GHG emission and at identifying environmental factors that control the soil $\mathrm{N}_{2} \mathrm{O}$ and $\mathrm{CH}_{4}$ fluxes.

\section{Materials and methods}

\subsection{Field experiment}

The study was conducted in forest stands in Rio Negrinho, SC, Brazil, between the southern latitudes of $26^{\circ} 23^{\prime} 11^{\prime \prime}$ and $26^{\circ} 23^{\prime} 19^{\prime \prime}$, western longitudes of $49^{\circ} 33^{\prime} 34^{\prime \prime}$ and $49^{\circ} 34^{\prime} 12^{\prime \prime}$, and altitudes of $\sim 900 \mathrm{~m}$. The climate in the region is subtropical humid ( $\mathrm{Cfb}$, Köppen), with a mean annual temperature of $15.5-17.0{ }^{\circ} \mathrm{C}$ and an annual rainfall of $1360-1670 \mathrm{~mm}$ (Thomé et al. 1999). The soil was classified as sandy clay loam humic Cambisol, according to a local soil survey and to the World Reference Base for Soil Resources (IUSS Working Group WRB 2015). A small variation was observed in clay content down the soil profile, ranging from the average of $340 \mathrm{~g} \mathrm{~kg}^{-1}$ at $0-5 \mathrm{~cm}$ and $341 \mathrm{~g} \mathrm{~kg}^{-1}$ at $20-30 \mathrm{~cm}$ to $400 \mathrm{~g} \mathrm{~kg}^{-1}$ at $75-100 \mathrm{~cm}$. Kaolinite and iron oxides were the main minerals in the clay fraction (Rodrigues 2016). Other soil information is presented in Table 1. Forest stands of loblolly pine (Pinus taeda L.) land use following natural forest clearing were selected:

- NF (natural forest), a mixed ombrophilous forest where, according to a local survey, the ten most abundant tree species in the study stand were Cyathea spp., Myrcia splendens, Dicksonia sellowiana, Myrsine umbellata, Nectandra megapotamica, Prunus myrtifolia, Pimenta pseudocaryophyllus, Araucaria angustifolia, Ocotea porosa and Drimys brasiliensis.

- P17, loblolly pine for 17 years, at a first rotation after clearing of the natural forest. In that clearing, trees were 
Table 1 Characteristics of the soil 0-5 cm layer, of the L layer of the forest floor and of trees in subtropical natural forest (NF) and in loblolly pine (Pinus taeda L.) land use for 17 years (P17), 32 years (P32) and
32 years thinned $(\mathrm{P} 32 \mathrm{t})$, with $\mathrm{P} 32$ and $\mathrm{P} 32 \mathrm{t}$ being in the second rotation. Rio Negrinho, SC, Brazil. Data adapted from Veloso et al. (2018)

\begin{tabular}{|c|c|c|c|c|}
\hline & NF & P17 & $\mathrm{P} 32$ & $\mathrm{P} 32 \mathrm{t}$ \\
\hline \multicolumn{5}{|l|}{ Soil } \\
\hline Particle density $\left(\mathrm{kg} \mathrm{dm}^{-3}\right)$ & $2.48 \pm 0.02 \mathrm{a}$ & $2.49 \pm 0.01 \mathrm{a}$ & $2.45 \pm 0.01 \mathrm{a}$ & $2.49 \pm 0.01 \mathrm{a}$ \\
\hline Bulk density $\left(\mathrm{kg} \mathrm{dm}^{-3}\right)$ & $0.65 \pm 0.03 \mathrm{a}$ & $1.03 \pm 0.05 \mathrm{c}$ & $0.86 \pm 0.06 \mathrm{~b}$ & $0.82 \pm 0.04 \mathrm{~b}$ \\
\hline Total porosity $\left(\mathrm{m}^{3} \mathrm{~m}^{-3}\right)$ & $0.74 \pm 0.03 \mathrm{a}$ & $0.58 \pm 0.02 \mathrm{c}$ & $0.64 \pm 0.02 \mathrm{~b}$ & $0.67 \pm 0.02 \mathrm{~b}$ \\
\hline Macroporosity $\left(\mathrm{m}^{3} \mathrm{~m}^{-3}\right)$ & $0.43 \pm 0.03 \mathrm{a}$ & $0.15 \pm 0.03 \mathrm{c}$ & $0.27 \pm 0.05 \mathrm{~b}$ & $0.32 \pm 0.04 \mathrm{ab}$ \\
\hline Microporosity $\left(\mathrm{m}^{3} \mathrm{~m}^{-3}\right)$ & $0.31 \pm 0.04 \mathrm{~b}$ & $0.44 \pm 0.02 \mathrm{a}$ & $0.38 \pm 0.03 \mathrm{ab}$ & $0.36 \pm 0.04 \mathrm{ab}$ \\
\hline \multicolumn{5}{|l|}{ L layer of forest floor * } \\
\hline $\mathrm{C}\left(\mathrm{g} \mathrm{kg}^{-1}\right)$ & $458 \pm 6 b$ & $471 \pm 3 \mathrm{a}$ & $477 \pm 10 \mathrm{a}$ & $474 \pm 4 \mathrm{a}$ \\
\hline $\mathrm{N}\left(\mathrm{g} \mathrm{kg}^{-1}\right)$ & $15.4 \pm 0.9 \mathrm{a}$ & $9.3 \pm 0.3 b$ & $9.5 \pm 0.5 b$ & $10.2 \pm 0.6 \mathrm{~b}$ \\
\hline $\mathrm{Si}\left(\mathrm{g} \mathrm{kg}^{-1}\right)$ & $1.7 \pm 0.3 \mathrm{~b}$ & $5.8 \pm 0.5 \mathrm{a}$ & $4.9 \pm 0.6 \mathrm{a}$ & $4.8 \pm 1.0 \mathrm{a}$ \\
\hline Lignin $\left(\mathrm{g} \mathrm{kg}^{-1}\right)$ & $351 \pm 16 b$ & $518 \pm 15 \mathrm{a}$ & $505 \pm 9 \mathrm{a}$ & $520 \pm 18$ a \\
\hline $\mathrm{C} / \mathrm{N}$ & $30 \pm 5 b$ & $51 \pm 2 \mathrm{a}$ & $50 \pm 1 \mathrm{a}$ & $47 \pm 2 \mathrm{a}$ \\
\hline Lignin/N & $23 \pm 5 b$ & $55 \pm 2 \mathrm{a}$ & $54 \pm 2 \mathrm{a}$ & $51 \pm 3 \mathrm{a}$ \\
\hline \multicolumn{5}{|l|}{ Tree } \\
\hline Height (m) & n.d. & $24.3 \pm 0.3$ & $18.4 \pm 1$ & $17.8 \pm 0.3$ \\
\hline Diameter at breast height $(\mathrm{cm}) *$ & $14 \pm 6$ & $29 \pm 5$ & $25 \pm 6$ & $26 \pm 5$ \\
\hline Wood yield $\left(\mathrm{m}^{3} \mathrm{ha}^{-1}\right.$ year $\left.^{-1}\right)$ & n.d. & $38.4 \pm 2.8$ & $41.5 \pm 1.7$ & n.d. \\
\hline
\end{tabular}

Means followed by the same letter do not differ significantly according to the Tukey test $(p<0.05)$

Tree height and wood yield were not determined (n.d.) in NF

*Data from the concurrent study of Veloso et al. (2018)

uprooted with a chain pulled by crawler tractors and windrowed (gathered into long piles called windrows) by a root rake with teeth working to a $30-\mathrm{cm}$ depth into the soil. There was no standard placement or dimension for windrows, which were then burnt. Soil was ripped to a depth of $\sim 80 \mathrm{~cm}$ (subsoil shanks).

- P32, loblolly pine for 32 years, at the 12 th year of a second rotation that succeeded a 20-year first rotation. During harvest of the first rotation, trees were cut, cleaned and sectioned using chainsaw. Harvesting residues were left on site and soil was then ripped $(\sim 80 \mathrm{~cm})$, between the rows of stumps of the first rotation. Since stumps were not uprooted and windrowed, the soil disturbance here was less intense than in the establishment of the first rotation right after clearing of the natural forest.

- P32t, similar to P32, but with selective $3 \times 1$ thinning (3 rows maintained and 1 removed) at the 11th year of this second rotation ( 1 year before the present study). The method used was stem only thinning (Higa 2005).

In each of the four forest stands, the working plots were located in similar soil and topographical conditions (5-8\% slope) and the longest distance being $1100 \mathrm{~m}$ between P17 and P32t, with NF and P32 in between.

\subsection{Soil $\mathrm{N}_{2} \mathrm{O}$ and $\mathrm{CH}_{4}$ fluxes}

Air samples were collected by using the static chamber method (Parkin and Venterea 2010), in 16 sampling sessions over 1 year (06 December 2012 to 29 November 2013), at nine sampling points per forest stand. The distance between sampling points was $\sim 10 \mathrm{~m}$, and that information, like the definition of number of sampling points, was defined in a previous study of the special variability (not published) of GHG emission in forest stands. A metal collar (internal $\varnothing 32 \mathrm{~cm}$ ) which served as a support for the chamber was inserted $5 \mathrm{~cm}$ into the soil at each sampling point, 1 week before the first sampling session. The lid was a PVC cylinder (height $35.7 \mathrm{~cm}$; $32.0 \mathrm{~cm}$ ) wrapped with reflective material for insulation. Internally, it was equipped with a $12-\mathrm{V}$ fan for mixing the headspace and with a thermometer. A rubber, with the same diameter of the metal collar, covered the perimeter of the lid and was used to airtight closed the chamber.

Each air sampling session started at 10:00 h, when chambers were deployed on the metal collars. Internal air samples were taken with polypropylene syringes $(20 \mathrm{~mL})$ at the chamber deployment (time 0 ) and 20, 40 and 60 min later and transferred into $12-\mathrm{mL}$ vials previously evacuated (Exetainer ${ }^{\circledR}$, Labco, UK). The $\mathrm{N}_{2} \mathrm{O}$ and $\mathrm{CH}_{4}$ concentrations were measured with a Shimadzu GC 2014 chromatograph 
equipped with a flame ionisation detector (FID) for $\mathrm{CH}_{4}$ and an electron capture detector (ECD) for $\mathrm{N}_{2} \mathrm{O}$.

The $\mathrm{N}_{2} \mathrm{O}$ or $\mathrm{CH}_{4}$ fluxes were calculated taking into account the (i) linear increase of the internal gas concentration during the 60 -min deployment, (ii) area covered by the chamber, (iii) volume, (iv) temperature and (v) pressure (assumed as $1 \mathrm{~atm}$ ) inside the chamber (Parkin and Venterea 2010). Daily $\mathrm{N}_{2} \mathrm{O}-\mathrm{N}$ emissions were estimated by linear interpolation, assuming that the gaseous flux by 09:00 to 11:00 a.m. represents the average daily flux (Bayer et al. 2016). Annual cumulative $\mathrm{N}_{2} \mathrm{O}-\mathrm{N}$ emissions were calculated by trapezoidal integration of the daily $\mathrm{N}_{2} \mathrm{O}-\mathrm{N}$ fluxes.

The cumulative annual emission was calculated by integrating the gaseous fluxes over the monitoring period (area under the curve).

\subsection{Net GHG emission and GHG intensity}

The annual net GHG emission from soil was calculated according to the equation:

Net GHG emission $=\mathrm{N}_{2} \mathrm{O}+\mathrm{CH}_{4}-\Delta \mathrm{SOC}$

where $\mathrm{N}_{2} \mathrm{O}$ and $\mathrm{CH}_{4}$ are the cumulative annual emissions of $\mathrm{N}_{2} \mathrm{O}$ and $\mathrm{CH}_{4}$ properly converted into $\mathrm{CO}_{2}-\mathrm{C}$ equivalent $\left(C_{\mathrm{eq}}\right)$ after considering the global warming potentials ( 298 for $\mathrm{N}_{2} \mathrm{O}$, 34 for $\mathrm{CH}_{4}$ ) and conversion factors, and $\triangle \mathrm{SOC}$ is the annual change in soil organic carbon (SOC) stock to 1-m depth, which was compiled from the concurrent study of Veloso et al. (2018) and assumed as a proxy of the net exchange of $\mathrm{CO}_{2}$ in the soil-atmosphere interface (Mosier et al. 2005). The $\triangle \mathrm{SOC}$ was calculated as the difference between the SOC stocks of the treatments (pine plantation) and the reference system (NF), divided by the time elapsed since the implementation of the experiment, i.e. 17, 32 and 32 for P17, P32 and $\mathrm{P} 32 \mathrm{~T}$, respectively. The $\triangle \mathrm{SOC}$ calculation is well described in Veloso et al. (2018).

The GHG intensity (GHGi) of wood production was given by the ratio between the annual net GHG emission and the annual wood yield, the wood yield volume being divided by the age of the stand. The wood volume was estimated based on the stem commercial height, the diameter at breast height (data from the concurrent study of Veloso et al. (2018)) and a form factor of 0.5 .

\subsection{Soil and forest floor parameters}

By the first air sampling session in December 2012, four soil core samples from the $0-5-\mathrm{cm}$ layer per forest stand were collected with metal cylinders $(3.5 \mathrm{~cm}$ height $\times 5.7 \mathrm{~cm}$ diameter) for determination of bulk density, total porosity, macroporosity and microporosity. Microporosity was the volume of water contained in core sample (initially saturated) after being subjected to $-6 \mathrm{kPa}$ in a tension table for $48 \mathrm{~h}$ (Leamer and Shaw 1941). Macroporosity was the difference between total porosity and microporosity. Total porosity was calculated from bulk and particle densities (Danielson and Sutherland 1986), the latter being measured by the ethyl alcohol method (Blake and Hartge 1986b). Soil bulk density was determined after drying samples at $105^{\circ} \mathrm{C}$ (Blake and Hartge 1986a).

At each air sampling session and sampling point, we measured the temperature, the water-filled pore space (WFPS) and the ammonium and nitrate concentrations in the same soil layer of $0-5 \mathrm{~cm}$, within a 2-m radius from each chamber. The soil temperature was measured with a skewer-type thermometer (Solotest 300). Three soil subsamples were collected with a core sampler to compose a sample per point. Part of the sample was used to determine the gravimetric moisture $\left(105^{\circ} \mathrm{C}\right)$ which, combined with information about soil total porosity and particle density, enabled the determination of the WFPS (Robertson and Groffman 2007). WFPS was calculated as the ratio between the volumetric water and total soil porosity, which was estimated from the soil density assuming soil particle density of $2.65 \mathrm{~g} \mathrm{~cm}^{-3}$. Ten grammes of that same humid soil sample was subjected to extraction with $30 \mathrm{~mL}$ of $2 \mathrm{M} \mathrm{KCl}$ for latter determination of ammonium by reaction with phenol (Mulvaney 1996) and absorbance reading at $640 \mathrm{~nm}$, and determination of nitrate by reduction with zinc (Heinzmann et al. 1984) and absorbance reading at $210 \mathrm{~nm}$.

In five air sampling sessions, from 12 April 2013 to 29 November 2013 and at 60-day intervals, we also determined the ammonium concentration in the $\mathrm{H}$ layer (Oa horizon) of the forest floor. Samples of that layer were taken from eight sampling points per forest stand, close to the metal collars. Approximately $5 \mathrm{~g}$ of sample was subjected to extraction in $30 \mathrm{~mL}$ of $2 \mathrm{M} \mathrm{KCl}$ and the extract was analysed for ammonium determination, following the same procedure used for soil. Concerning to forest floor, we also considered information of carbon, nitrogen, silicon, lignin, $\mathrm{C} / \mathrm{N}$ ratio and lignin/ $\mathrm{N}$ ratio of the L layer (litter, Oi layer), obtained in the concurrent study of Veloso et al. (2018).

\subsection{Statistical analyses}

Data were tested for and fulfilled the assumption of normality and homogeneity of variance, according to the tests of Kolmogorov-Smirnov and Bartlett $(p \leq 0.05)$, respectively. After that, the results were submitted to analysis of variance (ANOVA) and Tukey test $(p<0.05)$, using the statistical package ASSISTAT V7.6 beta and considering a complete randomised design, with nine replications (or eight replications), for forest floor ammonium (according to a previous study of spatial variability). We have considered each sampling point as a replicate, which suggests our results as 
preliminaries. Linear regressions were carried out using the Sigma Plot 12.0 software.

\section{Results}

\section{1 $\mathrm{N}_{2} \mathrm{O}$ and $\mathrm{CH}_{4}$ fluxes}

Among the forest stands, the soils under NF and P17 always showed the lowest $\mathrm{N}_{2} \mathrm{O}$ emission (Fig. 1a), which led to cumulative emissions $<1.0 \mathrm{~kg} \mathrm{~N}_{2} \mathrm{O}-\mathrm{N} \mathrm{ha}^{-1}$ year $^{-1}$ (Table 2), but in P32, the emissions were higher (Fig. 1a) and doubled the cumulative emission relative to $\mathrm{P} 17$ (1.65 vs. $0.77 \mathrm{~kg} \mathrm{~N} \mathrm{~N}_{2} \mathrm{O}$ $\mathrm{N} \mathrm{ha}{ }^{-1}$ year ${ }^{-1}$, Table 2). With respect to $\mathrm{CH}_{4}$, it always showed uptake into the soil, being the largest one in NF and the smallest in P17, while uptake in P32 was intermediate, but much closer to that of P17 (Fig. 1b). The cumulative $\mathrm{CH}_{4}$ consumption in $\mathrm{P} 17$ was only one-sixth of that in NF (1.83 vs $10.77 \mathrm{~kg} \mathrm{CH}_{4}-\mathrm{C} \mathrm{ha}^{-1}$ year $^{-1}$ ), but the soil tended to recover that consumption to a little more than $3.0 \mathrm{~kg} \mathrm{CH}_{4}-\mathrm{C}$ $\mathrm{ha}^{-1}$ year $^{-1}$ in P32 (Table 2). With respect to thinning (P32t), it did not change $\mathrm{N}_{2} \mathrm{O}$ and $\mathrm{CH}_{4}$ fluxes and cumulative

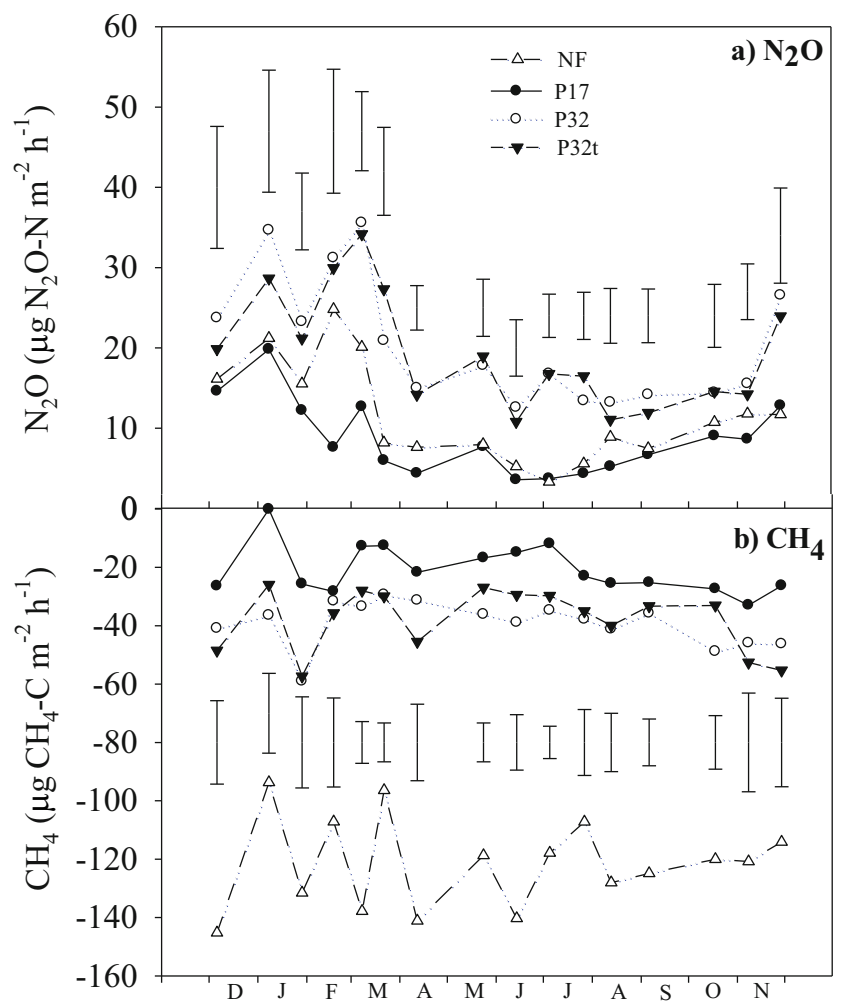

Fig. 1 Fluxes of $\mathrm{N}_{2} \mathrm{O}$ (a) and $\mathrm{CH}_{4}$ (b) from soil in subtropical natural forest (NF) and in loblolly pine (Pinus taeda L.) land use for 17 years (P17), 32 years (P32) and 32 years thinned (P32t), with P32 and P32t being in the second rotation. Rio Negrinho, SC, Brazil, from December 2012 to November 2013. Vertical bars indicate the least significant difference by the Tukey test $(p<0.05)$ emissions relative to unthinned pine (P32) (Fig. 1a, b; Table 2).

Seasonally, $\mathrm{CH}_{4}$ fluxes showed little variation (Fig. 1b), but $\mathrm{N}_{2} \mathrm{O}$ fluxes were higher in summer (mean of $23 \mu \mathrm{g}$ $\mathrm{N}_{2} \mathrm{O}-\mathrm{N} \mathrm{m}^{-2} \mathrm{~h}^{-1}$ across all forests in January, February and March) and lower in winter (mean of $10 \mu \mathrm{g} \mathrm{N} \mathrm{N}_{2} \mathrm{O}-\mathrm{N} \mathrm{m}^{-2} \mathrm{~h}^{-1}$ across all forests in July, August and September) (Fig. 1a).

\subsection{Net GHG emission and GHG intensity}

Considering the annual emissions of $\mathrm{N}_{2} \mathrm{O}$ and $\mathrm{CH}_{4}$ and the changes in SOC stock relative to NF (SOC data compiled from Veloso et al. (2018)), the net GHG emission was $2.8 \mathrm{Mg} \mathrm{C}_{\mathrm{eq}} \mathrm{ha}^{-1}$ year $^{-1}$ in P17, mainly governed by the loss of $2.7 \mathrm{Mg} \mathrm{ha}^{-1}$ year $^{-1}$ of SOC (Table 2). On the other hand, in $\mathrm{P} 32$, the net emission was $-1.1 \mathrm{Mg} \mathrm{C}_{\mathrm{eq}}$ ha $^{-1}$ year $^{-1}$ (negative emission means accumulation into the soil), mainly because of the SOC gain of $1.3 \mathrm{Mg} \mathrm{C}^{-1}$ year $^{-1}$ (Table 2). Considering those net emissions and the corresponding wood yields presented in Table 1, the GHG intensities per cubic metre of wood produced were $72.9 \mathrm{~kg} \mathrm{C}_{\mathrm{eq}}$ in $\mathrm{P} 17$ and $-26.5 \mathrm{~kg} \mathrm{C}$ eq in P32 (Table 2). As thinning did not affect $\mathrm{N}_{2} \mathrm{O}$ and $\mathrm{CH}_{4}$ fluxes, neither the SOC stock, it also did not affect the net GHG emission (Table 2).

\subsection{Soil and forest floor attributes}

Soil bulk density in the top $5 \mathrm{~cm}$ of soil varied across the forest stands, with the lowest bulk density in NF $\left(0.65 \mathrm{~kg} \mathrm{dm}^{-3}\right)$, highest in P17 $\left(1.03 \mathrm{~kg} \mathrm{dm}^{-3}\right)$ and intermediate in P32 $\left(0.86 \mathrm{~kg} \mathrm{dm}^{-3}\right)$ (Table 1). Accordingly, the largest macroporosity was in NF $\left(0.43 \mathrm{~m}^{3} \mathrm{~m}^{-3}\right)$, the minimum in P $17\left(0.15 \mathrm{~m}^{3} \mathrm{~m}^{-3}\right)$ and the intermediate in P32 $\left(0.27 \mathrm{~m}^{3} \mathrm{~m}^{-3}\right)$ (Table 1$)$.

Soil temperature was similar across the four forest stands, but varied seasonally from a mean of $8.8^{\circ} \mathrm{C}$ in July to $20.2^{\circ} \mathrm{C}$ in January (Fig. 2a), and that variation affected the $\mathrm{N}_{2} \mathrm{O}$ emissions, as demonstrated by the exponential increase of $\mathrm{N}_{2} \mathrm{O}$ fluxes with soil temperature $(p<0.0001$, Fig. 3a). The WFPS tended to be more constant over time, but differed among forests, being $\sim 80 \%$ in P17 and $<40 \%$ in NF (Fig. 2b). In P32, the WFPS was $\sim 60 \%$, lower than that in P17, but considerably higher than that in NF (Fig. 2b). In general, with increases in WFPS, the $\mathrm{N}_{2} \mathrm{O}$ fluxes followed a Gaussian behaviour $(p<0.001)$, with maximum emissions around $60 \%$ WFPS (Fig. 3b), while $\mathrm{CH}_{4}$ fluxes increased logarithmically with the increase in WFPS $(p<0.0001)$ (Fig. 4).

Regarding inorganic nitrogen, soils under NF have similar higher ammonium concentration that under $\mathrm{P} 17$ along time (mean of $6.35 \mathrm{mg} \mathrm{NH}_{4}{ }^{+}-\mathrm{N} \mathrm{kg}^{-1}$ throughout the year) but had higher ammonium concentrations than in P32 and P32t (mean of $4.14 \mathrm{mg} \mathrm{NH}_{4}^{+}-\mathrm{N} \mathrm{kg}^{-1}$ ) (Fig. 2c), in 11 of those 18 sampling days (Fig. 2c). For nitrate, it was clear that the lowest 
Table 2 Cumulative soil emission of $\mathrm{N}_{2} \mathrm{O}$ and $\mathrm{CH}_{4}$, annual change in soil organic carbon (SOC) stock ( $\triangle \mathrm{SOC})$, and annual net GHG emission and its intensity (GHGi) in subtropical natural forest (NF) and in loblolly pine (Pinus taeda L.) land use for 17 years (P17), 32 years (P32) and 32 years thinned $(\mathrm{P} 32 \mathrm{t})$, with $\mathrm{P} 32$ and $\mathrm{P} 32 \mathrm{t}$ being in the second rotation. Rio Negrinho, SC, Brazil

\begin{tabular}{|c|c|c|c|c|}
\hline & NF & P17 & P32 & $\mathrm{P} 32 \mathrm{t}$ \\
\hline \multicolumn{5}{|l|}{$\mathrm{N}_{2} \mathrm{O}$} \\
\hline $\mathrm{kg} \mathrm{N}_{2} \mathrm{O}-\mathrm{N}$ ha $^{-1}$ year $^{-1}$ & $0.94 \pm 0.04 \mathrm{~b}$ & $0.77 \pm 0.08 \mathrm{~b}$ & $1.65 \pm 0.13 \mathrm{a}$ & $1.59 \pm 0.13 \mathrm{a}$ \\
\hline $\mathrm{kg} \mathrm{C}_{\text {eq }}$ ha $^{-1}$ year $^{-1}$ & $120 \pm 9 b$ & $98 \pm 16 b$ & $211 \pm 15 \mathrm{a}$ & $203 \pm 5 a$ \\
\hline \multicolumn{5}{|l|}{$\mathrm{CH}_{4}$} \\
\hline $\mathrm{kg} \mathrm{CH}_{4}-\mathrm{C} \mathrm{ha}^{-1}$ year $^{-1}$ & $-10.77 \pm 0.34 \mathrm{c}$ & $-1.83 \pm 0.13 \mathrm{a}$ & $-3.35 \pm 0.22 b$ & $-3.20 \pm 0.22 b$ \\
\hline $\mathrm{kg} \mathrm{C}_{\text {eq }}$ ha $^{-1}$ year $^{-1}$ & $-75 \pm 1 \mathrm{c}$ & $-13 \pm 2 \mathrm{a}$ & $-23 \pm 2 b$ & $-22 \pm 3 b$ \\
\hline \multicolumn{5}{|l|}{$\Delta \mathrm{SOC}$ stock } \\
\hline $\mathrm{Mg} \mathrm{C}_{\mathrm{eq}} \mathrm{ha}^{-1}$ year $^{-1}$ & $0.0 \pm 0.3$ & $-2.7 \pm 0.3 b$ & $1.3 \pm 0.1 \mathrm{a}$ & $1.1 \pm 0.2 \mathrm{a}$ \\
\hline \multicolumn{5}{|l|}{ Net GHG emission } \\
\hline $\mathrm{MgCC}_{\mathrm{eq}} \mathrm{ha}^{-1}$ year $^{-1}$ & $0.1 \pm 0.0$ & $2.8 \pm 0.1$ & $-1.1 \pm 0.1$ & $-0.9 \pm 0.1$ \\
\hline \multicolumn{5}{|l|}{ GHGi } \\
\hline $\mathrm{kg} \mathrm{C}_{\mathrm{eq}} \mathrm{m}^{-3}$ wood & - & $72.9 \pm 3.4$ & $-26.5 \pm 2.5$ & - \\
\hline
\end{tabular}

Cumulative emissions of $\mathrm{N}_{2} \mathrm{O}$ and $\mathrm{CH}_{4}$ from 06 December 2012 to 29 November 2013, with negative sign meaning consumption from the atmosphere into the soil

$\triangle \mathrm{SOC}$ refers to the annual change in soil SOC stock up to 1-m depth obtained by Veloso et al. (2018), with negative sign meaning emission from the soil into the atmosphere

Net GHG emission $=\mathrm{N}_{2} \mathrm{O}+\mathrm{CH}_{4}-\Delta \mathrm{SOC}$, with negative sign meaning consumption from the atmosphere into the soil

GHGi is the ratio between net GHG emission and the annual wood yield reported in Table 1, with negative sign meaning consumption from the atmosphere into the soil

Means followed by the same letter do not differ statistically by the Tukey test $(p<0.05)$

concentration was observed in $\mathrm{P} 17$ soil compared with that in $\mathrm{NF}, \mathrm{P} 32$ and P32t (mean of 1.80 vs. mean of $6.21-9.71 \mathrm{mg}$ $\mathrm{NO}_{3}{ }^{-} \mathrm{N} \mathrm{kg}^{-1}$ ) (Fig. 2d).

In the $\mathrm{H}$ layer of the forest floor, the ammonium concentration was low in June (winter) and high in November (spring end) (Fig. 2e). In general, the $\mathrm{N}_{2} \mathrm{O}$ fluxes increased linearly with $\mathrm{H}$ layer ammonium concentration $(p<0.0001)$ (Fig. 3c).

\section{Discussion}

\subsection{Nitrous oxide emissions}

The soils under NF and P17 had the lowest $\mathrm{N}_{2} \mathrm{O}$ emissions (Fig. 1a, Table 2), but due to very distinct reasons. In NF, the low emission was attributed to the lowest WFPS $(<40 \%$ throughout the year (Fig. 2b)), and possibly associated with the largest soil macroporosity of $0.43 \mathrm{~m}^{3} \mathrm{~m}^{-3}$ (Table 1). For being undisturbed, the soil under NF was certainly subjected to the long-term effects of roots and litter at developing a crumbly aerated soil structure with less anaerobic microsites for $\mathrm{N}_{2} \mathrm{O}$ production by denitrification, the main process of soil $\mathrm{N}_{2} \mathrm{O}$ formation. Interestingly though, that low soil $\mathrm{N}_{2} \mathrm{O}$ emission in NF contrasts the fact that NF soil had one of the highest concentrations of ammonium and nitrate (Fig. 2c, d). This is probably because of the high $\mathrm{N}$ cycling in the NF soil, which resulted from the combination of higher nitrogen deposition via plant residues and more favourable oxygen availability (aeration) for nitrification. Soil moisture/structure condition was thus an important factor that reduced $\mathrm{N}_{2} \mathrm{O}$ emissions, regardless of the higher availability of inorganic nitrogen. The little $\mathrm{N}_{2} \mathrm{O}$ emitted from NF soil was probably produced by nitrification, the main $\mathrm{N}_{2} \mathrm{O}$ producing process when WFPS is between 35 and 60\% (Bateman and Baggs 2005).

Differently, the low $\mathrm{N}_{2} \mathrm{O}$ emission in $\mathrm{P} 17$ soil was attributed to the highest WFPS, around $80 \%$ throughout the year (Fig. 2b) and possibly related to the lowest macroporosity of $0.15 \mathrm{~m}^{3} \mathrm{~m}^{-3}$ (Table 1). Under such condition of high WFPS and less aeration, two hypotheses might explain the low $\mathrm{N}_{2} \mathrm{O}$ emissions in P17. The first is the low nitrification rate, once oxygen was less available for ammonium oxidation into nitrate (Linn and Doran 1984), limiting the $\mathrm{N}_{2} \mathrm{O}$ production either by nitrification per se or by the subsequent denitrification. The lowest nitrification rate is supported by the fact that the P17 soil had one of the highest concentrations of ammonium (Fig. 2c) and the lowest of nitrate (Fig. 2d), showing that although the ammonium be the subtract to nitrification, low availability of oxygen was restrictive to nitrification. The second hypothesis is that any $\mathrm{N}_{2} \mathrm{O}$ that might have been formed was promptly denitrified into $\mathrm{N}_{2}$, in a process which is favoured by the reduced conditions enabled by high WFPS (Davidson et al. 2000). 

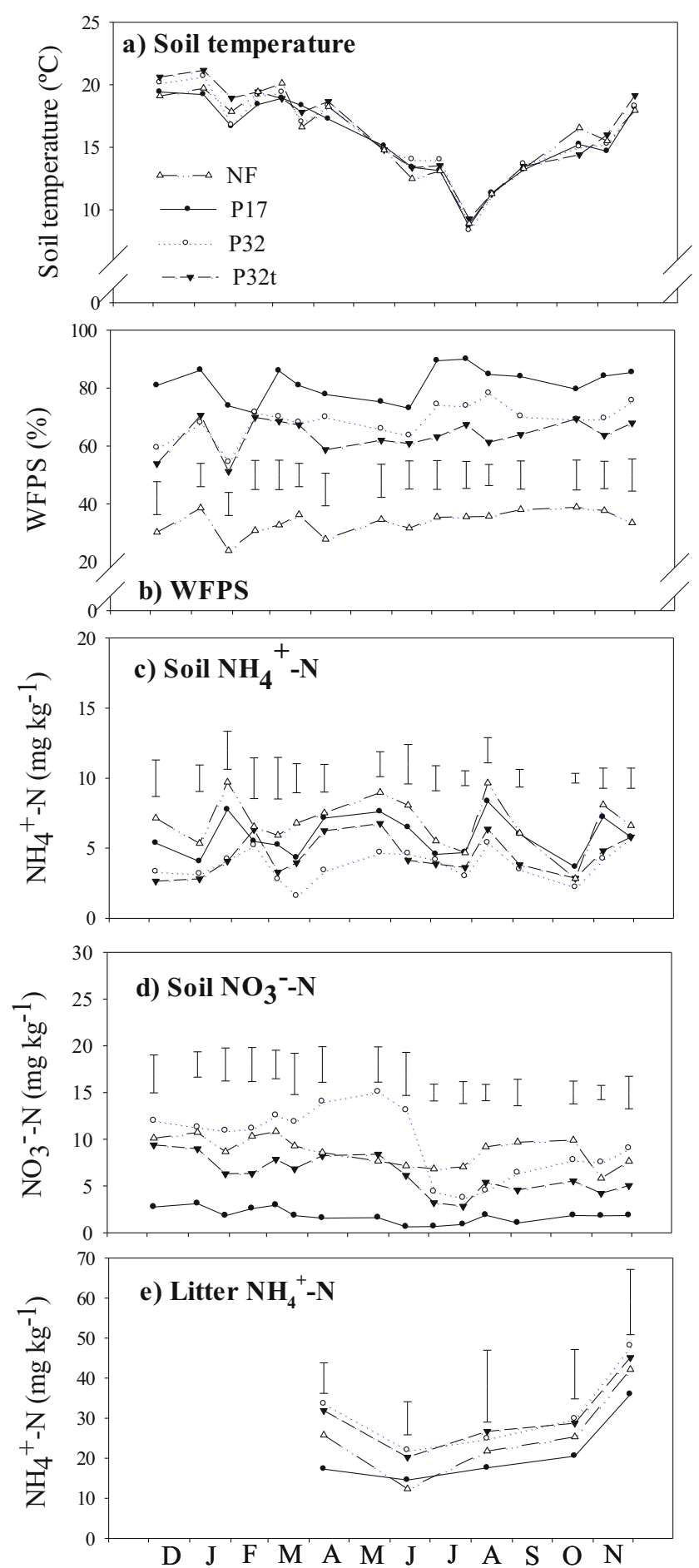

Fig. 2 Temperature (a), water-filled pore space (WFPS) (b), ammonium (c) and nitrate (d) in the $0-5 \mathrm{~cm}$ of soil, and ammonium in the $\mathrm{H}$ layer of the forest floor (e) in subtropical natural forest (NF) and in loblolly pine (Pinus taeda L.) land use for 17 years (P17), 32 years (P32) and 32 years thinned (P32t), with P32 and P32t being in the second rotation. Rio Negrinho, SC, Brazil, from December 2012 to November 2013. Vertical bars indicate the least significant difference by the Tukey test $(p<0.05)$

In fact, the ultimate cause of the low $\mathrm{N}_{2} \mathrm{O}$ emission associated with high WFPS in P17 was the intense soil disturbance by chaining and windrowing during the natural forest clearing. That damaged the original soil structure condition built by the long-term action of roots and litter in the NF soil. This structural damage became evident with the reduction of the macroporosity from $0.43 \mathrm{~m}^{3} \mathrm{~m}^{-3}$ in NF soil to $0.15 \mathrm{~m}^{3} \mathrm{~m}^{-3}$ under P17 (Table 1), possibly limiting aeration and increasing microsites of anaerobiosis.

Soils under pine land use for 32 years, thinned or not, emitted the highest amount of $\mathrm{N}_{2} \mathrm{O}$ (Fig. 1a, Table 2), which refutes our hypothesis that long-term loblolly pine land use decreases $\mathrm{N}_{2} \mathrm{O}$ emission. We had expected that improvements in soil structure and aeration over time would reduce $\mathrm{N}_{2} \mathrm{O}$ losses by denitrification. What might explain this unexpected higher $\mathrm{N}_{2} \mathrm{O}$ emission in P32 and P32t was again the WFPS status of the soil. The WFPS at $\sim 60 \%$ throughout the year in P32 or P32t (Fig. 2b) is very close to the value of $60 \%$ that Davidson et al. (2000) reported as ideal for denitrification. This is consistent with the maximum $\mathrm{N}_{2} \mathrm{O}$ emission in the Gaussian relationship that we found between emission and WFPS (Fig. 3b). This is a moisture condition also favourable to nitrification (Linn and Doran 1984), which per se produces $\mathrm{N}_{2} \mathrm{O}$ (Wrage et al. 2001), and to the supply of nitrate for denitrification into $\mathrm{N}_{2} \mathrm{O}$. Additionally, another factor that could have contributed to the higher $\mathrm{N}_{2} \mathrm{O}$ emission in second rotation was their trend for higher ammonium concentrations in the $\mathrm{H}$ layer of the forest floor (Figs. 2e and 3e), but unfortunately, that factor was secondarily investigated in our study to support clear evidence.

Results from studies conducted in temperate forests were not conclusive on the effect of forest land use on soil $\mathrm{N}_{2} \mathrm{O}$ emission. Peichl et al. (2010) did not observe clear effects of stand age on $\mathrm{N}_{2} \mathrm{O}$ fluxes in a 4-67-year-old sequence of white pine forest in Ontario. Meanwhile, Christiansen and Gundersen (2011) found that older stands (40 years) of oak or Norway spruce in Denmark emitted more $\mathrm{N}_{2} \mathrm{O}$ than younger stands (13-17 years) and attributed that to the increased soil nitrogen availability (less demand by tree) and to the decreased bulk density and increased $\mathrm{N}_{2} \mathrm{O}$ diffusivity in the soil of older stands. But perhaps one explanation for the higher $\mathrm{N}_{2} \mathrm{O}$ emission in the older stands of the study of Christiansen and Gundersen (2011) would also be the decrease of the initially high soil moisture to the level of $60 \%$ WFPS favourable to $\mathrm{N}_{2} \mathrm{O}$ production (Davidson et al. 2000).

Regarding the lack of effect of thinning on $\mathrm{N}_{2} \mathrm{O}$ emissions, it is very possible that the 1-year time period following the operation was very short for pronounced changes in soil structure and macroporosity (Table 1) and therefore in WFPS (Fig. b) that affects $\mathrm{N}_{2} \mathrm{O}$ emission.

\subsection{Methane emissions}

As a governing factor of $\mathrm{N}_{2} \mathrm{O}$ fluxes, the WFPS was also a major controller of $\mathrm{CH}_{4}$ fluxes (Fig. 4). The lower WFPS in 


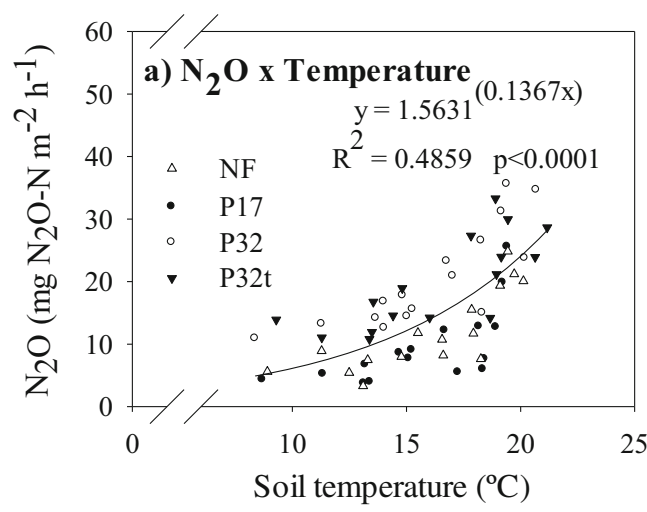

Fig. 3 Regression between $\mathrm{N}_{2} \mathrm{O}$ flux and temperature (a), water-filled pore space (WFPS) (b) in the $0-5 \mathrm{~cm}$ of soil and ammonium in the $\mathrm{H}$ layer of the forest floor (c) in subtropical natural forest (NF) and in

NF soil enabled by the larger macroporosity led to substantial $\mathrm{CH}_{4}$ uptake (Fig. 1b) and thus to the cumulative consumption of $10.77 \mathrm{~kg} \mathrm{CH}_{4}-\mathrm{C} \mathrm{ha}^{1}$ year $^{-1}$ (Table 2). With improved soil oxygen diffusivity, the methanotrophic oxidation activity increased to a level to allow such consumption of $\mathrm{CH}_{4}$ (Konda et al. 2010; Smith et al. 2003). That consumption represents a much greater $\mathrm{CH}_{4}$ sink when compared with $5.6 \mathrm{~kg} \mathrm{CH}_{4}-\mathrm{C}$ $\mathrm{ha}^{1}$ year $^{-1}\left(7.5 \mathrm{~kg} \mathrm{CH}_{4} \mathrm{ha}^{1}\right.$ year $\left.{ }^{-1}\right)$ that Dutaur and Verchot (2007) estimated as the maximum soil consumption, in a worldwide assessment across several soil use systems.

In $\mathrm{P} 17$ soil, the sixfold reduction in $\mathrm{CH}_{4}$ consumption relative to NF soil (Table 2) was also attributed to the higher WFPS, which was probably related to soil structural alterations like macroporosity reduction caused during the conversion of NF into pine plantation. That result is similar to the $62-$ $76 \%$ reduction in $\mathrm{CH}_{4}$ absorption after conversion of natural forest into monoculture forest reported for temperate regions (Born et al. 1990; Butterbach-Bahl and Papen 2002). With

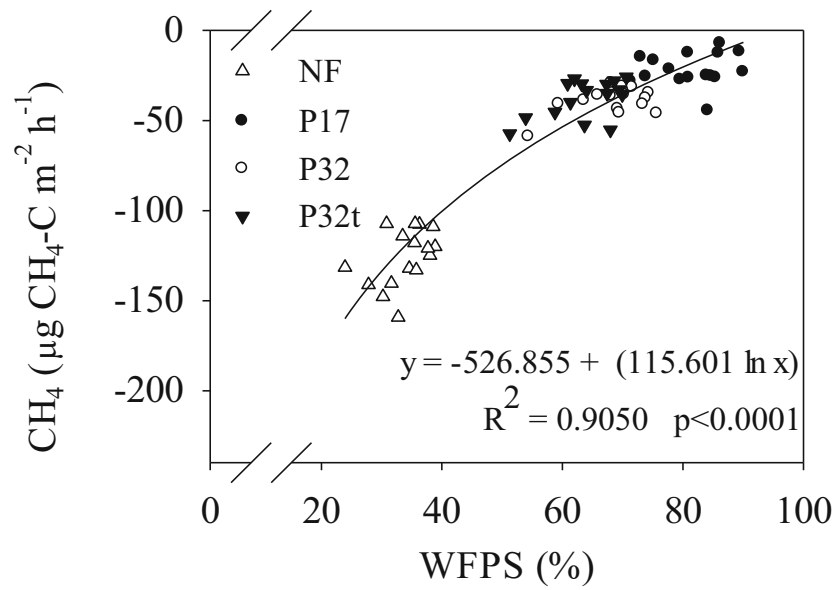

Fig. 4 Regression between the $\mathrm{CH}_{4}$ flux and water-filled pore space (WFPS) in the $0-5 \mathrm{~cm}$ of soil in subtropical natural forest (NF) and in loblolly pine (Pinus taeda L.) land use for 17 years (P17), 32 years (P32) and 32 years thinned (P32t), with P32 and P32t being in the second rotation. Rio Negrinho, SC, Brazil

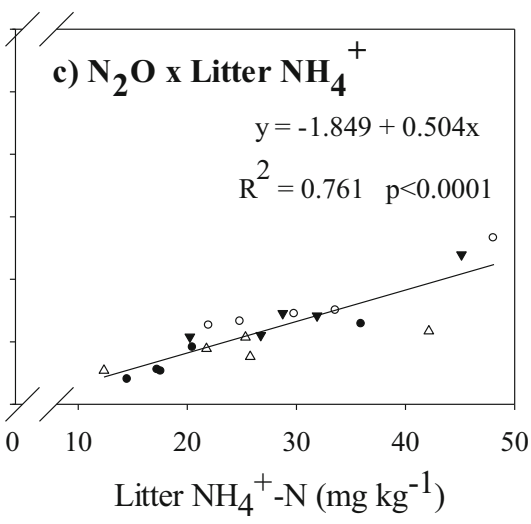

loblolly pine (Pinus taeda L.) land use for 17 years (P17), 32 years (P32) and 32 years thinned (P32t), with P32 and P32t being in the second rotation. Rio Negrinho, SC, Brazil

higher WFPS in P17, the more humid and anaerobic conditions of soil probably constrained methanotrophic and favoured methanogenic communities (Le Mer and Roger 2001). In addition to the WFPS, monoterpenes commonly released during the decomposition of pine needles (Lerdau et al. 1997) could have also constrained the methanotrophs (Amaral and Knowles 1998) compared with NF, where there is no pine needles.

On the other hand, despite the presence of monoterpenes, the main factor that favoured the $\mathrm{CH}_{4}$ consumption rise in $\mathrm{P} 32$ relative to P17 (Table 2) was possibly the improvement of soil structure in long-term pine land use (Fig. 4), indicated by the larger macroporosity (Table 1) and lower WFPS in P32 (Fig. 2b). Results clearly show that long-term cultivation of pine increases $\mathrm{CH}_{4}$ consumption, up to $3.2 \mathrm{~kg} \mathrm{CH}_{4}$ $\mathrm{ha}^{-1}$ year ${ }^{-1}$, and thus confirm our hypothesis that $\mathrm{CH}_{4}$ consumption in pine land use increases with time compared with younger stands. Similarly, Peichl et al. (2010) found that a 4year-old pine plantation emitted $0.4 \mathrm{~kg} \mathrm{CH}_{4}-\mathrm{C} \mathrm{ha}^{-1}$ year $^{-1}$ while a 65 -year-old consumed $1.5 \mathrm{~kg} \mathrm{CH}_{4}-\mathrm{C} \mathrm{ha}^{-1}$ year $^{-1}$ in Ontario. Yet, even with $\mathrm{CH}_{4}$ consumption increasing in $\mathrm{P} 32$ soil, it still remained far lower than the consumption in $\mathrm{NF}$ soil.

Thinning also did not affect $\mathrm{CH}_{4}$ fluxes, for the same reason that 1 year was probably not enough to significantly affect macroporosity and WFPS, regulators of $\mathrm{CH}_{4}$ fluxes. Similarly, Sullivan et al. (2008) did not find any influence of tree thinning on $\mathrm{CH}_{4}$ flux in the south-west USA.

\subsection{Net GHG emission and GHG intensity}

The behaviours of the short-term (P17) and of the long-term (P32) pine land use were completely distinct with respect to the soil net GHG emission. An expressive emission of $2.8 \mathrm{Mg}$ $\mathrm{C}_{\text {eq }}$ ha $^{-1}$ year $^{-1}$ to the atmosphere occurred in the first 17 years, but a mitigation of $1.1 \mathrm{Mg} \mathrm{C}_{\mathrm{eq}} \mathrm{ha}^{-1}$ year $^{-1}$ occurred in the long-term 32 years of pine. As a result, the GHG intensity 
pointed that, to produce $1 \mathrm{~m}^{3}$ of wood, soil emitted $72.9 \mathrm{~kg}$ $\mathrm{C}_{\mathrm{eq}}$ in the first 17 years, but mitigated on average $26.5 \mathrm{~kg} \mathrm{C}$ eq in the whole 32 years, evidencing that in the long term, the cultivation of forest not only produces wood but also serves as an important sink for GHG in the soil.

Despite the significant changes that the pine plantation promoted on soil $\mathrm{N}_{2} \mathrm{O}$ and $\mathrm{CH}_{4}$ fluxes, the net GHG emission was ultimately determined by changes in soil SOC stock $(\triangle \mathrm{SOC})$ (Table 2). The SOC change accounted for $85-96 \%$ of the modular sum of all gaseous fluxes $\left(\sum\left|\mathrm{N}_{2} \mathrm{O}\right|+\left|\mathrm{CH}_{4}\right|+\right.$ $|\Delta \mathrm{TOC}|)$, while $\mathrm{N}_{2} \mathrm{O}$ contributed to $3-14 \%$ and $\mathrm{CH}_{4}$ to less than $1 \%$. That indicates that approaches to soil GHG mitigation in forest fields should firstly invest efforts towards SOC sequestration, which probably will bring additional and concurrent benefits in terms of soil structure amelioration and thus $\mathrm{CH}_{4}$ and $\mathrm{N}_{2} \mathrm{O}$ mitigation. Previous studies with conifer plantations in temperate regions had also registered the relatively high contribution of $\mathrm{CO}_{2}$ exchanges ( $>85 \%$, but here including biomass) in ecosystem GHG balance (Ball et al. 2007; Peichl et al. 2014). Even so, $\mathrm{N}_{2} \mathrm{O}$ and $\mathrm{CH}_{4}$ exchanges do have a role in the soil-atmosphere gaseous balance that must be appropriately accounted.

Although our results are preliminary, we have found interesting tendencies that can help us to understand better the GHG fluxes under pine forest in a subtropical region and to guide future studies.

\section{Conclusions}

During the first 17 years after the clearing of natural subtropical forest, loblolly pine land use reduces soil $\mathrm{CH}_{4}$ consumption but also reduces soil $\mathrm{N}_{2} \mathrm{O}$ emission, probably because of the effects of soil disturbances at clearing that reduced aeration porosity and increased water-filled pore space. That less aerated soil environment hinders methanotrophy and also nitrification, or if denitrification occurs, may lead to complete denitrification into $\mathrm{N}_{2}$. However, the second rotation (32 years after the clearing of natural subtropical forest) of loblolly pine land use improves soil structure and brings soil moisture and aeration to a condition favourable (WFPS $\sim 60 \%$ ) to methanotrophy and to an optimal combination of nitrification and subsequent denitrification into $\mathrm{N}_{2} \mathrm{O}$. Hence, increased $\mathrm{CH}_{4}$ consumption and increased $\mathrm{N}_{2} \mathrm{O}$ emission refute our initial hypothesis that $\mathrm{N}_{2} \mathrm{O}$ emission decreased with long-term pine plantations. In spite of everything, soil carbon change is the major driver of the net GHG emission. Soil carbon losses for 17 years, together with reduced $\mathrm{CH}_{4}$ consumption, turn the soil of pine plantation into a remarkable source of GHG in the short term. However, together with increased $\mathrm{CH}_{4}$ consumption, soil carbon sequestration turns the soil of second rotation with pine plantation into a notable sink of GHG (despite emitting more $\mathrm{N}_{2} \mathrm{O}$ ), with positive impacts at mitigating anthropogenic emissions.

Acknowledgements The authors appreciate the helpful contribution of Modo Battistella Reflorestamento, for granting access to the forest stands, and of the field and laboratory staff of Embrapa and UFPR.

Funding This study was financially supported by Saltus Project (Macroprograma 1 Grandes Desafios Nacionais - Embrapa) and by CNPq (Brazilian Scientific Council). Scholarships were funded by Capes (Brazilian Ministry of Education) and by CNPq.

Data availability The datasets generated during and/or analysed during the current study are available from the corresponding author on reasonable request.

\section{Compliance with ethical standards}

Conflict of interest The authors declare that they have no conflict of interest.

\section{References}

Amaral JA, Knowles R (1998) Inhibition of methane consumption in forest soils by monoterpenes. J Chem Ecol 24:723-734. https:// doi.org/10.1023/a:1022398404448

Ball T, Smith KA, Moncrieff JB (2007) Effect of stand age on greenhouse gas fluxes from a Sitka spruce [Picea sitchensis (Bong.) Carr.] chronosequence on a peaty gley soil. Glob Chang Biol 13:2128 2142. https://doi.org/10.1111/j.1365-2486.2007.01427.x

Bateman EJ, Baggs EM (2005) Contributions of nitrification and denitrification to $\mathrm{N}_{2} \mathrm{O}$ emissions from soils at different water-filled pore space. Biol Fertil Soils 41:379-388. https://doi.org/10.1007/s00374005-0858-3

Bayer C, Gomes J, Zanatta JA, Vieira FCB, Dieckow J (2016) Mitigating greenhouse gas emissions from a subtropical Ultisol by using longterm no-tillage in combination with legume cover crops. Soil Till Res 161:86-94. https://doi.org/10.1016/j.still.2016.03.011

Blake GR, Hartge KH (1986a) Bulk density. In: Klute A (ed) Methods of soil analysis. Part 1. Physical and minerological methods, 2nd edn. SSSA, Madison, pp 363-382

Blake GR, Hartge KH (1986b) Particle density. In: Klute A (ed) Methods of soil analysis. Part 1. Physical and minerological methods, 2nd edn. SSSA, Madison, pp 377-382

Born M, Dörr H, Levin I (1990) Methane consumption in aerated soils of the temperate zone. Tellus B 42:2-8. https://doi.org/10.1034/j.16000889.1990.00002.x

Butterbach-Bahl K, Papen H (2002) Four years continuous record of $\mathrm{CH}_{4}$-exchange between the atmosphere and untreated and limed soil of a N-saturated spruce and beech forest ecosystem in Germany. Plant Soil 240:77-90. https://doi.org/10.1023/a:1015856617553

Christiansen JR, Gundersen P (2011) Stand age and tree species affect $\mathrm{N}_{2} \mathrm{O}$ and $\mathrm{CH}_{4}$ exchange from afforested soils. Biogeosciences 8: 2535-2546. https://doi.org/10.5194/bg-8-2535-2011

Danielson RE, Sutherland PL (1986) Porosity. In: Klute A (ed) Methods of soil analysis - part 1: physical and mineralogical methods. SSSA, Madison, pp 443-461

Davidson EA, Keller M, Erickson HE, Verchot LV, Veldkamp E (2000) Testing a conceptual model of soil emissions of nitrous and nitric oxides. Bioscience 50:667-680 
Dutaur L, Verchot LV (2007) A global inventory of the soil $\mathrm{CH}_{4}$ sink. Glob Biogeochem Cycles 21:9. https://doi.org/10.1029/ $2006 \mathrm{gb} 002734$

Firestone MK, Davidson EA (1989) Microbial basis of $\mathrm{NO}$ and $\mathrm{N}_{2} \mathrm{O}$ production and consumption in soil. In: Andreae MO, Schimel D (eds) Exchange of trace gases between terrestrial ecosystems and the atmosphere. Wiley, pp 7-21

Fisher RF (1995) Amelioration of degraded rain-forest soils by plantations of native trees soil. Sci Soc Am J 59:544-549

Grassi G, House J, Dentener F, Federici S, den Elzen M, Penman J (2017) The key role of forests in meeting climate targets requires science for credible mitigation. Nat Clim Chang 7:220-226. https://doi.org/10. 1038/nclimate3227

Gregorich EG, Rochette P, van den Bygaart AJ, Angers DA (2005) Greenhouse gas contributions of agricultural soils and potential mitigation practices in eastern, Canada. Soil Tillage Res 83:53-72

Heinzmann FX, Miyazawa M, Pavan MA (1984) Determinação de nitrato em extratos de solos ácidos por espectrofotometria de absorção ultravioleta. Rev Bras Ci Solo 8:159-163

Higa RCV (2005) Dinâmica de carbono de Pinus taeda L. voltadas a exigências climáticas e práticas silviculturais [Relatório de pósdoutorado]. University of Florida, Gainesville

IPCC (2014) Climate change 2014: synthesis report. IPCC, Geneva

IUSS Working Group WRB (2015) World reference base for soil resources 2014, update 2015: International soil classification system for naming soils and creating legends for soil maps. World Soil Resources Reports No. 106. FAO, Rome

Konda R, Ohta S, Ishizuka S, Heriyanto J, Wicaksono A (2010) Seasonal changes in the spatial structures of $\mathrm{N}_{2} \mathrm{O}, \mathrm{CO}_{2}$, and $\mathrm{CH}_{4}$ fluxes from Acacia mangium plantation soils in Indonesia. Soil Biol Biochem 42:1512-1522. https://doi.org/10.1016/j.soilbio.2010.05.022

Lal R (2004) Soil carbon sequestration impacts on global climate change and food security. Science 304:1623-1627

Le Mer J, Roger P (2001) Production, oxidation, emission and consumption of methane by soils: a review. Eur J Soil Biol 37:25-50

Leamer RW, Shaw B (1941) A simple apparatus for measuring noncapillary porosity on an extensive scale. J Am Soc Agron 33: 1003-1008

Lerdau M, Litvak M, Palmer P, Monson R (1997) Controls over monoterpene emissions from boreal forest conifers. Tree Physiol 17:563569

Linn DM, Doran JW (1984) Effect of water-filled pore space on carbon dioxide and nitrous oxide production in tilled and nontilled soils soil. Sci Soc Am J 48:1267-1272

Mosier AR, Halvorson AD, Peterson GA, Robertson GP, Sherrod L (2005) Measurement of net global warming potential in three agroecosystems. Nutr Cycl Agroecosyst 72:67-76

Mosier AR, Halvorson AD, Reule CA, Liu XJJ (2006) Net global warming potential and greenhouse gas intensity in irrigated cropping systems in northeastern Colorado. J Environ Qual 35: 1584-1598

Mulvaney RL (1996) Nitrogen - inorganic forms. In: Sparks DL et al (eds) Methods of soil analysis: part 3 chemical methods. Soil Science Society of America, Madison, pp 1123-1184
Parkin TB, Venterea RT (2010) Sampling protocols. Ch 3: chamber-based trace gas flux measurements. In: Follett RF (ed) GRACEnet Sampling protocols. pp 1-39. www.ars.usda.gov/research/ GRACEnet

Peichl M, Arain MA, Ullah S, Moore TR (2010) Carbon dioxide, methane, and nitrous oxide exchanges in an age-sequence of temperate pine forests. Glob Chang Biol 16:2198-2212. https://doi.org/10. 1111/j.1365-2486.2009.02066.x

Peichl M, Arain AM, Moore TR, Brodeur JJ, Khomik M, Ullah S, Restrepo-Coupé N, McLaren J, Pejam MR (2014) Carbon and greenhouse gas balances in an age sequence of temperate pine plantations. Biogeosciences 11:5399-5410. https://doi.org/10.5194/bg11-5399-2014

Post WM, Kwon KC (2000) Soil carbon sequestration and land-use change: processes and potential. Glob Chang Biol 6:317-327

Robertson GP, Groffman PM (2007) Nitrogen transformations. In: Paul EA (ed) Soil microbiology, ecology and biochemistry, 3rd edn. Academic Press, San Diego, pp 341-364

Rodrigues ANA (2016) Formas de alumínio em solos cultivados com Pinus taeda L. nos estados do Paraná e Santa Catarina. Tese de Doutorado, Unviersidade Federal do Paraná

Smith KA, Ball T, Conen F, Dobbie KE, Massheder J, Rey A (2003) Exchange of greenhouse gases between soil and atmosphere: interactions of soil physical factors and biological processes. Eur J Soil Sci 54:779-791. https://doi.org/10.1046/j.1351-0754.2003.0567.x

Smith P, Haberl H, Popp A, Erb KH, Lauk C, Harper R, Tubiello FN, de Siqueira Pinto A, Jafari M, Sohi S, Masera O, Böttcher H, Berndes G, Bustamante M, Ahammad H, Clark H, Dong H, Elsiddig EA, Mbow C, Ravindranath NH, Rice CW, Robledo Abad C, Romanovskaya A, Sperling F, Herrero M, House JI, Rose S (2013) How much land-based greenhouse gas mitigation can be achieved without compromising food security and environmental goals? Glob Chang Biol 19:2285-2302. https://doi.org/10.1111/ gcb. 12160

Sullivan B, Kolb TE, Hart SC, Kaye JP, Dore S, Montes-Helu M (2008) Thinning reduces soil carbon dioxide but not methane flux from southwestern USA ponderosa pine forests. For Ecol Manag 255: 4047-4055. https://doi.org/10.1016/j.foreco.2008.03.051

Thomé VMR et al (1999) Zoneamento Agroecológico e Socioeconômico de Santa Catarina vol CD-ROOM. Epagri, Florianópolis

Veloso MG, Dieckow J, Zanatta JA, Bayer C, Higa RCV, Brevilieri RC, Comerford NB, Stoppe AM (2018) Reforestation with loblolly pine can restore the initial soil carbon stock relative to a subtropical natural forest after 30 years. Eur J For Res 137:593-604. https:// doi.org/10.1007/s10342-018-1127-y

Wrage N, Velthof GL, van Beusichem ML, Oenema O (2001) Role of nitrifier denitrification in the production of nitrous oxide. Soil Biol Biochem 33:1723-1732. https://doi.org/10.1016/s0038-0717(01) 00096-7

Publisher's note Springer Nature remains neutral with regard to jurisdictional claims in published maps and institutional affiliations. 